\title{
Evaluation of African Cultivated Rice Oryza glaberrima for Resistance to Bacterial Blight
}

Gustave Djedatin, AfricaRice, 01 BP2031 Cotonou, and Université d'Abomey-Calavi, 01 BP 526 Cotonou, Bénin; Marie-Noëlle Ndjiondjop, AfricaRice; Thierry Mathieu, UMR 5096 IRD-CNRS-U.Perpignan, Laboratoire Génome et Développement des Plantes, 34394 Montpellier Cedex 5, France; Casiana M. Vera Cruz, Plant Breeding, Genetics and Biotechnology Division, International Rice Research Institute, Los Baños, Laguna, Philippines; Ambaliou Sanni, Université d'Abomey-Calavi; and Alain Ghesquière and Valérie Verdier, UMR 5096 IRD-CNRS-U.Perpignan, Laboratoire Génome et Développement des Plantes, 34394 Montpellier Cedex 5, France

\begin{abstract}
Djedatin, G., Ndjiondjop, M.-N., Mathieu, T., Vera Cruz, C. M., Sanni, A., Ghesquière, A., and Verdier, V. 2011. Evaluation of African cultivated rice Oryza glaberrima for resistance to bacterial blight. Plant Dis. 95:441-447.

Xanthomonas oryzae pv. oryzae is the causal agent of bacterial blight in rice, one of the most devastating diseases of rice worldwide. African $X$. oryzae pv. oryzae strains belong to a clear genetic group distinct from those of Asia. Three new races of the pathogen were characterized among strains from West Africa. We evaluated 107 Oryza glaberrima accessions for resistance to bacterial blight under greenhouse conditions. Six-week-old seedlings were inoculated with five different African X. oryzae pv. oryzae strains originating from the West African nations of Burkina and Mali and representing different races (A1, A2, and A3). Philippine X. oryzae pv. oryzae strain PXO86 (race 2) was

also used. Most (48\%) of the accessions of O. glaberrima were highly susceptible to $X$. oryzae pv. oryzae strains from Burkina, while 20 and 36 were resistant to $X$. oryzae pv. oryzae strains from Mali and the Philippines, respectively. CAPS markers and dot blot assays were used for detection of resistance genes $x a 5$ and $X a 21$ from a selected set of $O$. glaberrima accessions. Our results suggest that the O. glaberrima germplasm contains a narrow genetic base for resistance to $X$. oryzae pv. oryzae. Sources of resistance identified among $O$. glaberrima are recommended for rice breeding programs to develop bacterial blightresistant cultivars for West Africa.
\end{abstract}

One of the most important diseases that affects rice is bacterial blight (BB), caused by Xanthomonas oryzae pv. oryzae. This disease, which occurs as a vascular wilt at the early stages of crop growth and as a leaf blight at later stages, severely affects rice production worldwide $(24,25)$. It is especially prevalent in irrigated and rain-fed lowland rice-growing areas. Yield losses caused by $X$. oryzae pv. oryzae typically range from 20 to $30 \%$ and can be as high as $50 \%$ in some areas of Asia (1). The disease was reported in 1980 from most African rice-growing countries $(29,35)$. The recent intensification and expansion of rice areas in the absence of known resistant cultivars contributes to the increase of the disease in Africa. In 2003 and, more recently, in 2009, extensive surveys in three West African countries indicated a high incidence of BB $(9,39)$. Because host resistance is still the most effective way to control the disease in Asia, breeding efforts to develop rice cultivars with resistance to BB are urgently needed in West Africa. To date, over $30 \mathrm{Xa}$ genes have been identified (21). So far, six resistance genes (Xa1, Xa5, xa13,Xa21,Xa26, and Xa27) have been cloned and characterized as encoding different types of proteins, suggesting multiple mechanisms of resistance-genemediated $X$. oryzae pv. oryzae resistance $(46,47)$. Xa3/Xa26 and $X a 21$ encode leucine-rich repeat (LRR) receptor kinase type

\section{Corresponding author: V. Verdier, E-mail: valerie.verdier@ird.fr}

Current address of V. Verdier: UMR RPB, IRD-CIRAD-UM2,BP 64501, 34394 Montpellier cedex 5, France.

Current address of T. Mathieu: Centre d'Ecologie Fonctionnelle et Evolutive CEFE.

* The $e$-Xtra logo stands for "electronic extra" and indicates that a supplemental table not included in the print edition is available online.

Accepted for publication 23 November 2010.

doi:10.1094/PDIS-08-10-0558

(C) 2011 The American Phytopathological Society proteins $(42,49)$ which are the only two characterized plant LRR receptor kinase resistance proteins that mediate race-specific resistance. Xal encodes a nucleotide binding-LRR protein (50) and $\mathrm{Xa27}$ a novel protein (10). The recessive genes $x a 5$ and $x a 13$ encode a gamma subunit of transcription factor IIA $(13,15)$ and a novel plasma membrane protein (7), respectively. Xa21 has been widely exploited in breeding programs and remains effective in many rice-growing regions (18).

Marker-assisted selection (MAS) for recessive resistance genes is not always efficient because it involves the use of markers that are only indirectly linked to the target genes and there is the risk of the markers being separated from the trait by recombination. Recently, functional markers were developed for $x a 13, x a 5$, and $\mathrm{Xa21}$ (14). To facilitate the application of MAS, low-cost applications such as dot blot assays for single-nucleotide protein (SNP) detection have been developed (40). Recent applications for targeted introgression of $x a 5, x a 13$, and $X a 21$ genes into different rice cultivars using MAS have been successfully reported $(19,43)$.

The genetic characterization of a collection of $X$. oryzae pv. oryzae strains revealed unique features of African $X$. oryzae pv. oryzae strains compared with Asian ones (9). African X. oryzae pv. oryzae strains have a smaller number of transcription activator-like (TAL) effector genes and insertion sequence (IS) elements in their genome (9). A race is a group of strains sharing a common phenotype of virulence or avirulence to a set of host cultivars. Three new races (A1, A2, and A3) were characterized (9). Race A1 is present in Niger, Burkina, and Cameroon, and is virulent on near-isogenic lines (NILs) carrying resistance genes Xa3, xa8, Xa10, Xa11, xa13, Xa14, and $\mathrm{Xa} 21$ and avirulent to those carrying $\mathrm{Xa4}, \mathrm{xa}$, and $\mathrm{Xa}$. Race A2 is reported from Burkina and race A3 is reported from Mali. Differences between races A2 and A 3 are based on their reaction to the parental line IR24; race A3 is avirulent and race A2 is virulent (9).

Oryza glaberrima $(2 \mathrm{n}=24$, AA) is the African cultivated species of rice that was domesticated in the Niger River delta of West Africa in approximately 1500 B.C.E. from the wild relative $O$. barthii (syn. O. breviligulata). O. glaberrima is isolated from $O$. sativa by reproductive barriers and has lower genetic diversity than $O$. sativa $(31,37)$. After the introduction of Asian rice (O. sativa) to Africa, 
$O$. glaberrima was progressively abandoned in favor of $O$. sativa, which has higher yields (16). Nevertheless, O. glaberrima is still grown in marginal production areas (Mali, Guinea, and Burkina), where local adaptation to adverse conditions is recognized by farmers. Indeed, $O$. glaberrima has many useful traits such as weed competitiveness, drought tolerance (23), submergence tolerance, and tolerance to soil acidity, salt, iron toxicity $(28,36)$, and aluminum toxicity (4). O. glaberrima is also reported as highly resistant to several diseases and pests, such as Rice yellow mottle virus $(3,26,44)$, blast $(41)$, sheath blight, nematodes $(22,33)$, stem borer and hispa, stalked eye fly (2), and African gall midge (30,48). Recently, sources of resistance to different Indian $X$. oryzae pv. oryzae pathotypes have been identified among $O$. glaberrima accessions (45). Some of the interesting traits of $O$. glaberrima are being combined with high-yielding traits of $O$. sativa to develop NERICA, the "New Rice for Africa" (16).

Although there are few $\mathrm{Xa}$ resistance genes that are detectable or desirable to work with (9), sources of resistance to African $X$. oryzae pv. oryzae strains are still lacking and, therefore, highly desirable for the development of resistant rice cultivars for sustainable crop production in West Africa. The objective of this study was to evaluate a representative collection of $O$. glaberrima accessions that originated from Africa for its resistance to African $X$. oryzae pv. oryzae strains.

\section{Materials and Methods}

Germplasm evaluated. In total, 107 accessions of $O$. glaberrima from the Africa Rice Center gene bank (Cotonou, Benin) were selected according to specific geographical origin characteristics such as drought tolerance and resistance to other rice diseases (Fig. 1). Also included were O. glaberrima accessions CG14 (accession IRGC 96717) and MG12 (accession IRGC 103544) that are being used to develop new genetic resources at the Africa Rice Center (12). The population structure of $O$. glaberrima using simple sequence repeat markers was conducted on some of the accessions selected in our study (38). Eight $O$. sativa cultivars (IR24, IR64, ITA212, ITA306, BG90-2, Kogoni [subspecies indica], Azucena, and WAB165 [subspecies japonica]) were also included in this study. Azucena is known to be highly susceptible to African $X$. oryzae pv. oryzae strains and was used as a susceptible control in each of our screenings. Plants were grown under controlled conditions $\left(28^{\circ} \mathrm{C}, 80 \%\right.$ humidity, and 12 -h day length) in the greenhouse at IRD Montpellier.

Inoculation and disease assessment. Five strains of $X$. oryzae pv. oryzae were used in this study. X. oryzae pv. oryzae strains $\mathrm{BAI} 3$ and BAI4 from Burkina correspond to race A1 and A2, respectively. X. oryzae pv. oryzae strain MAI1 from Mali belongs to race A3 (Table 1). Two other African $X$. oryzae pv. oryzae strains, NAI8 from Niger (race A1) and CFBP1949 from Mali (race A3), were tested on a subset of $10 \mathrm{O}$. glaberrima accessions. We also included Philippine $X$. oryzae pv. oryzae strain PXO86, which belongs to Philippine race 2 . All strains were stored in $15 \%$ glycerol at $-80^{\circ} \mathrm{C}$. Before inoculation, strains were streaked on PSA medium (10 $\mathrm{g}$ of peptone, $10 \mathrm{~g}$ of sucrose, $1 \mathrm{~g}$ of glutamic acid, and $16 \mathrm{~g}$ of Bacto agar per liter of $\mathrm{H}_{2} \mathrm{O}, \mathrm{pH}$ 7.0). The inoculum was prepared by suspending bacterial cells from PSA in sterile, distilled

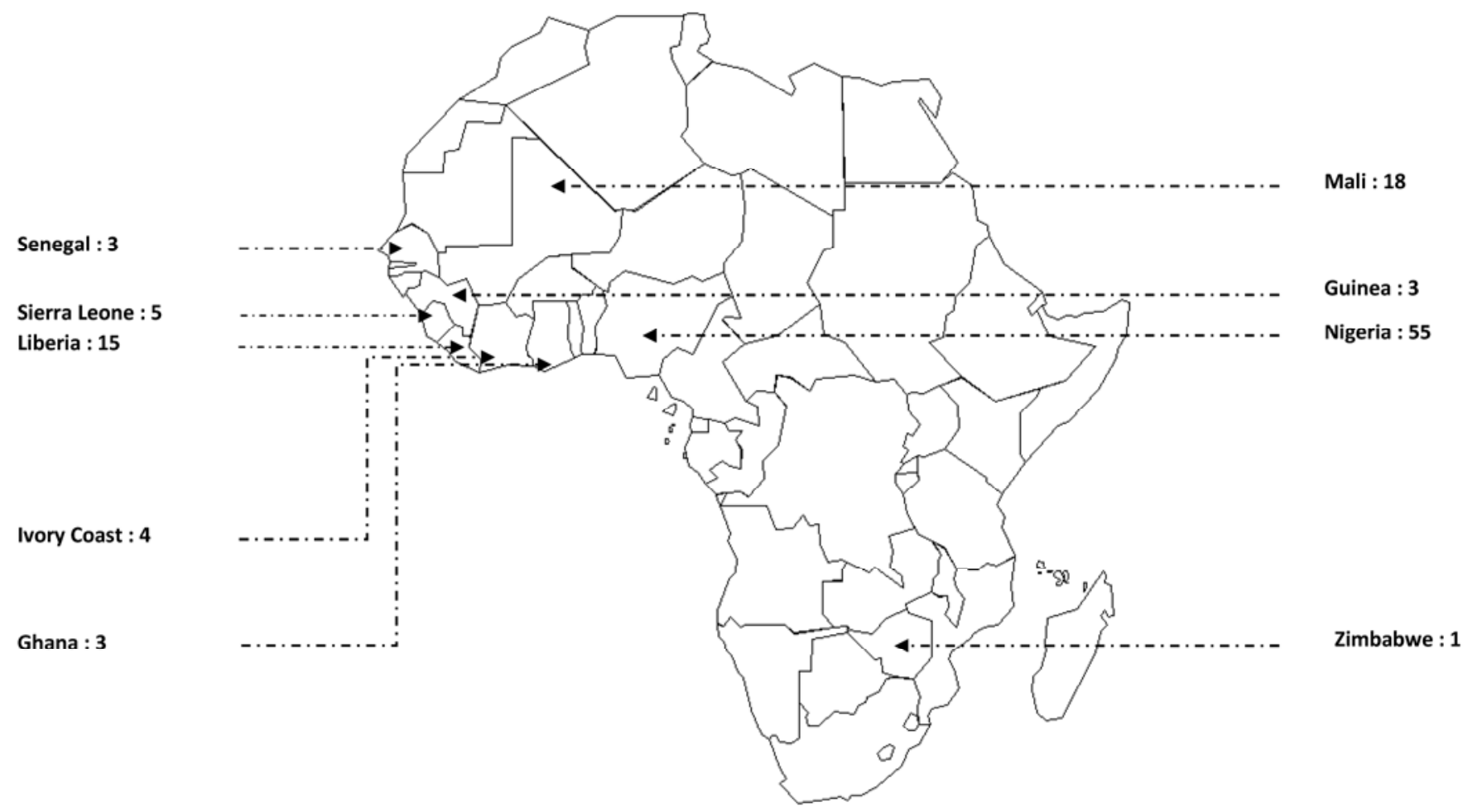

Fig. 1. Geographical location of the Oryza glaberrima origin and number of accessions tested per country.

Table 1. Characteristics of Xanthomonas orzyzae pv. oryzae strains used and their average reactions on 107 Oryza glaberrima accessions

\begin{tabular}{|c|c|c|c|c|c|c|c|c|c|c|c|c|}
\hline \multirow[b]{2}{*}{ Strains } & \multirow[b]{2}{*}{ Origin } & \multirow[b]{2}{*}{ Race } & \multicolumn{4}{|c|}{ No. of different reactions induced ${ }^{a}$} & \multicolumn{3}{|c|}{ Lesion length $(\mathrm{cm})^{b}$} & \multicolumn{3}{|c|}{ Virulence level $^{\text {b }}$} \\
\hline & & & $\mathbf{R}$ & MR & MS & $\mathbf{S}$ & Min & Mean & Max & Min & Mean & Max \\
\hline BAI3 & Burkina & A1 & 0 & 2 & 15 & 90 & 5.68 & 17.75 & 22.9 & 2 & 4.27 & 5 \\
\hline BAI4 & Burkina & A2 & 0 & 3 & 17 & 87 & 6.15 & 18.21 & 31.4 & 2 & 4.36 & 5 \\
\hline MAI1 & Mali & A3 & 20 & 51 & 20 & 16 & 0.93 & 9.04 & 24.18 & 1 & 2.54 & 5 \\
\hline PXO86 & Philippines & Phil2 & 36 & 41 & 10 & 20 & 1.25 & 8.36 & 22.45 & 1 & 2.33 & 5 \\
\hline
\end{tabular}

a Resistant (R), moderately resistant (MR), moderately susceptible (MS), and susceptible (S) as described in the text.

${ }^{\mathrm{b}}$ Min = minimum and Max = maximum; virulence level as described in the text. 
water at an optical density at $600 \mathrm{~nm}$ of 0.2 , bearing approximately $10^{8} \mathrm{CFU} / \mathrm{ml}$. Inoculations were conducted under greenhouse conditions at $28^{\circ} \mathrm{C}$ and $80 \%$ relative humidity. Plants were inoculated at 45 days after sowing using the leaf-clipping method (17). Lesion length (in centimeters) was measured 21 days post inoculation. The disease reaction of each accession was classified according to the mean lesion length, as follows: resistant if lesion length was $<5 \mathrm{~cm}$, moderately resistant if between 5 and $10 \mathrm{~cm}$, moderately susceptible if between 10 and $15 \mathrm{~cm}$, and susceptible if $>15 \mathrm{~cm}$. Virulence was defined as the capacity of the bacteria to infect the plants and was based on lesion length using the following scale, as described previously (45): $0=$ no obvious lesion, $1=$ a lesion length of 1 to 3 $\mathrm{cm}, 2=4$ to $7 \mathrm{~cm}, 3=8$ to $12 \mathrm{~cm}, 4=13$ to $18 \mathrm{~cm}$, and $5=>19 \mathrm{~cm}$.

Experimental design and data analysis. Two replicate trials for disease assays were done. Each trial consisted of an assessment of 115 rice accessions (107 O. glaberrima and 8 O. sativa) against each of the four respective strains. Per strain, 10 seeds were sown for each accession and inoculated. Two fully expanded leaves were inoculated per plant. The 10 replicate plants per accession were sown on row in a small seed tray, each containing eight randomly selected accessions. The seed trays were arranged in a completely randomized design in the greenhouse. For some accessions, germination was not $100 \%$; such plants were considered as missing data in the analysis. In this way, the percentage of missing data (i.e., nongerminated seed) in each trail (per 2,300 total seeds planted) was as follows: $1.3,2.26,4.43$, and $2.43 \%$ for the $X$. oryzae pv. oryzae strains BAI3, BAI4, MAI1, and PXO86, respectively, in trial 1 , and $0.69,1.04,1.91$, and $0.86 \%$ in trial 2 .

A combined trial data analysis was performed by strain based on a linear mixed model using the nlme package of R V.2.7.2 (32,34). The model was defined as $y_{\mathrm{ijk}} \approx \mu+\alpha_{\mathrm{j}}+\beta_{\mathrm{k}}+\varepsilon_{\mathrm{ijk}}$, where $y_{\mathrm{ijk}}$ is the disease reaction (leaf lesion length) of individual $i$ for accession $j$ in trial $k, \mu$ is the intercept, $\alpha_{\mathrm{j}}$ is the effect of the accession $j, \beta_{\mathrm{k}}$ is the effect of the trial $k$, and $\varepsilon$ is the residual of the model. Accession was considered as a fixed effect and trial was considered as a random effect. The existence of significant differences $(P<0.001)$ in lesion lengths among accessions was assessed using the $F$ test. Comparisons of accessions was based on best linear unbiased estimators for each accession $j$ with respect to each strain, as $y_{\mathrm{g}}^{\prime}=\mu+$ $\alpha_{j}$, where $\mu$ is the intercept and $\alpha_{j}$ is the fixed effect of the accession $j$ (fixed effect coefficients for the mixed model fitted object).

Detection of resistance alleles $x a 5$ and $X a 21$. Twelve $O$. glaberrima accessions that originated from different geographical areas and had resistant, moderately resistant, moderately susceptible, or susceptible reactions to $X$. oryzae pv. oryzae strains were selected and genotyped to identify the presence or absence of $x a 5$ and $\mathrm{Xa21}$ resistance alleles. The NILs IRBB5 and IRBB21, which are known to carry $x a 5$ and $X a 21$, respectively, were used as positive controls. The primer pairs used for amplification of DNA fragment covering the SNP regions of $x a 5$ and $X a 21$ were $x a 5-6 \mathrm{~F}$ : 5'GATAGCAGCATTTCCAAGAG3', xa5-4R: 5'GATTCCTTT AGCAAGGTGTG3', Xa21F: 5'ATAGCAACTGATTGCTTGG3', and Xa21R: 5'CGATCGGTATAACAGCAAAAC3'.

For $x a 5$ detection, DNA was extracted as described previously (13). Approximately 10 to $20 \mathrm{ng}$ of genomic DNA were used in a $25-\mu \mathrm{l}$ polymerase chain reaction (PCR), performed in an automated thermal cycler according to the following cycles: initial denaturation at $94^{\circ} \mathrm{C}$ for $5 \mathrm{~min} ; 33$ cycles of denaturation at $94^{\circ} \mathrm{C}$ for $30 \mathrm{~s}$, annealing at $51^{\circ} \mathrm{C}$ for $30 \mathrm{~s}$, and extension at $72^{\circ} \mathrm{C}$ for $1 \mathrm{~min}$; and a final extension step at $72^{\circ} \mathrm{C}$ for $5 \mathrm{~min}$. Restriction endonuclease digestion was done directly on the PCR products using BsrI or SmlI enzymes (14). Digest products were run on a $2.5 \%$ agarose gel. The CAPS marker size of $x a 5$ was $949 \mathrm{bp}$.

Xa21 detection was done by dot-blot-SNP analysis (40; International Rice Research Institute, unpublished). DNA fragments covering the SNP sites were amplified by PCR using the Xa21 primers as indicated above and with the following conditions: $94^{\circ} \mathrm{C}$ for $4 \mathrm{~min}$; 34 cycles of denaturation at $94^{\circ} \mathrm{C}$ for $1 \mathrm{~min}$, annealing at $55^{\circ} \mathrm{C}$ for $1 \mathrm{~min}$, and extension at $72^{\circ} \mathrm{C}$ for $2 \mathrm{~min}$; and a final extension step at $72^{\circ} \mathrm{C}$ for $8 \mathrm{~min}$. The PCR target size of $\mathrm{Xa} 21$ was
1,400 and $1,250 \mathrm{bp}$ for the resistance and susceptible alleles, respectively.

The diluted PCR products (1:20) were denatured in a solution of $0.4 \mathrm{~N} \mathrm{NaOH}$ and $10 \mathrm{mM}$ EDTA, and dot blotted onto a nylon membrane (Nytran; Schleicher \& Schuell, Germany). DNA was fixed to the membrane using a UV-cross linker. Blots were prehybridized at $42^{\circ} \mathrm{C}$ as recommended by the manufacturer using prewarmed Hyb buffer (Roche DIG Easy Hyb), for at least 30 min. The probes $(10 \mu \mathrm{M})$ prepared by resuspending digoxigenin (DIG)labeled oligo probes in Tris-EDTA, $\mathrm{pH}$ 8, were denatured at $68^{\circ} \mathrm{C}$ and immediately added to prewarmed hybridization buffer. Blots were then hybridized at $60^{\circ} \mathrm{C}$ for at least $6 \mathrm{~h}$. Filters were washed with three solutions: the first of $2 \times \mathrm{SSC}(1 \times \mathrm{SSC}$ is $0.15 \mathrm{M} \mathrm{NaCl}$ plus $0.015 \mathrm{M}$ sodium citrate) and $0.1 \%$ sodium dodecyl sulfate (SDS) for $20 \mathrm{~min}$, followed by two washings with $1 \times$ SSC and $0.1 \%$ SDS for $10 \mathrm{~min}$ each, and a final wash with $0.1 \times$ SSC and $0.1 \%$ SDS for 20 min. Signals were detected with a DIG Nucleic Acid Detection Kit, NBT/BCIP (Roche, Switzerland).

\section{Results}

Identification of resistant accessions among $O$. glaberrima. The $X$. oryzae pv. oryzae strains tested by the leaf clipping method had different reactions on the $O$. glaberrima accessions (Fig. 2; Table 1). For all strains, accessions had significantly different lesion lengths and the relative differences were not consistent among strains $(P<0.0001)$. The $O$. glaberrima accessions that were resistant to African $X$. oryzae pv. oryzae strains originated from different geographical areas (Supplementary Table 1). Among the 20 accessions of $O$. glaberrima that are highly resistant to X. oryzae pv. oryzae Malian strains (race A3), 4 originated from Mali and the 16 others from Guinea, Ivory Coast, Liberia, Nigeria, Senegal, Sierra Leone, and Zimbabwe. No correlation was observed between the resistance levels and the geographical origin of the $O$. glaberrima accessions and that of the $X$. oryzae pv. oryzae strains used (Supplementary Table 1).

For O. glaberrima, 20 and 36 accessions showed a high level of resistance to $X$. oryzae pv. oryzae strains MAI1 (race A3) and PXO86 (Phil race 2), respectively (Fig. 2; Table 1), with 10 accessions highly resistant to both strains (Table 2). Nineteen accessions were moderately resistant to both MAI1 and PXO86 (Table 2). Six accessions that had a high level of resistance to MAI1 were moderately resistant to PXO86 (Table 2). Conversely, 17 accessions among the 51 found as moderately resistant to MAI1 showed a high level of resistance to PXO86 (Table 2). Only two accessions were moderately resistant to BAI3 (race A1) while BAI4 (race A2) induced a moderate resistance reaction in three accessions (Table 2). Fifteen accessions were highly susceptible to all African $X$. oryzae pv. oryzae strains (Table 2). Although strains NAI8 (race A1 from Niger) and CFBP1949 (race A3 from Mali) were tested on only 10 accessions, the reactions matched the results obtained with strains BAI3 (race A1) and MAI1 (race A3). Strain CFBP1949 (race A3) induced resistant, moderately resistant, and moderately susceptible reactions, whereas strain NAI8 (race A1) induced only susceptible reactions in all accessions.

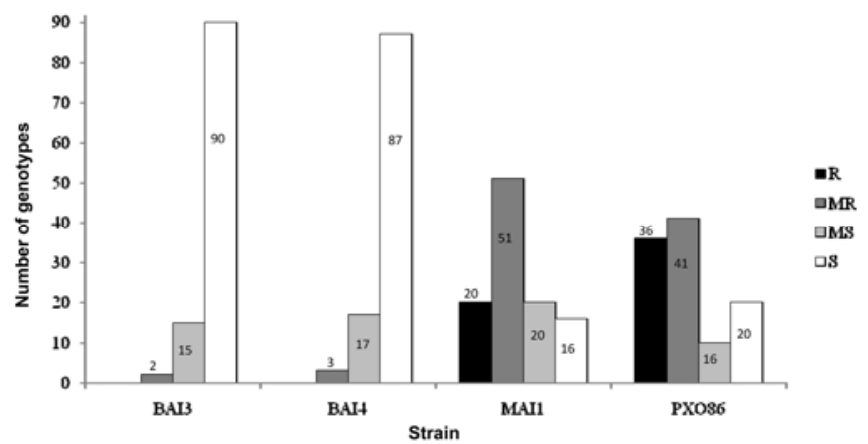

Fig. 2. Number of different types of reactions induced by Xanthomonas oryzae pv. oryzae. 
For $O$. sativa, five of eight accessions were highly resistant to the African $X$. oryzae pv. oryzae strains (Table 3). Two other accessions (IR24 and ITA212) had variable reactions. Azucena was highly susceptible to all the strains tested. All the $O$. sativa accessions were highly susceptible to the Phil $X$. oryzae pv. oryzae strain PXO86.

Virulence of $X$. oryzae pv. oryzae strains. The mean lesion length ( \pm standard error) induced by African $X$. oryzae pv. oryzae strains MAI1 (race A3), BAI3 (race A1), and BAI4 (race A2) on 107 O. glaberrima accessions was $9.04 \pm 0.23,17.25 \pm 0.28$, and $18.21 \pm 0.28 \mathrm{~cm}$, respectively (Table 1 ). The mean lesion length induced by CFBP1949 (race A3) and NAI8 (race A1) was 8 and 19 $\mathrm{cm}$, respectively (data not shown). Differences in virulence were observed among African strains and Philippine strain PXO86, with an average ranging from $2.33 \pm 0.12$ to $4.36 \pm 0.07$ (Table 1). Particularly, strains BAI3 and BAI4 from Burkina caused remarkable symptoms on all tested $O$. glaberrima accessions, with an average virulence level (VL) of 4.27 and 4.36, respectively (Table 1) and up to 5 on O. sativa IR24 and Azucena (Table 3). Strain MAI1 (race A3) induced significantly less severe symptoms on $O$. glaberrima accessions, with an average VL $=2.54$ (Fig. 2; Table 1). Strain MAI1 exhibited also a low VL on almost all $O$. sativa cultivars (VL =1) except Azucena $(\mathrm{VL}=4)$ (Table 3). Strain PXO86 (Phil race 2) exhibited a similar VL on $O$. glaberrima accessions $(\mathrm{VL}=2.33$ ) but was highly virulent on all $O$. sativa cultivars (Fig 2; Tables 1 and 3). Strains MAI1 and PXO86 were very similar in terms of virulence on $O$. glaberrima. Strain NAI8 (race A1) showed high virulence $(\mathrm{VL}=4.4)$, whereas CFBP 1949 (race A3) showed low virulence $(\mathrm{VL}=2.3$ ) on 10 accessions of $O$. glaberrima (data not shown).

$x a 5$ and $\mathrm{Xa21}$ resistance allele detection among $O$. glaberrima. Twelve $O$. glaberrima accessions originating from diverse geographical areas (Table 4) and three $O$. sativa accessions (IR24 and the derived NILs IRBB5 and IRBB21) were genotyped for the presence or absence of $x a 5$ and $X a 21$ alleles (Table 4). As expected, our results revealed that the NILs IRBB5 and IRBB21

Table 2. Reactions of Oryza glaberrima accessions for resistance to Xanthomonas oryzae pv. oryzae strains ${ }^{\mathrm{a}}$

\begin{tabular}{|c|c|c|c|c|}
\hline \multirow[b]{3}{*}{ Reactions } & \multicolumn{4}{|c|}{ X. oryzae pv. oryzae strains } \\
\hline & \multicolumn{3}{|r|}{ African } & \multirow{2}{*}{$\begin{array}{c}\text { Asian } \\
\text { PXO86 (Phil race 2) }\end{array}$} \\
\hline & BAI3 (A1) & BAI4 (A2) & MAI1(A3) & \\
\hline \multirow[t]{2}{*}{$\mathrm{R}$} & $\ldots$ & $\ldots$ & \multicolumn{2}{|c|}{ CG14, TOG5284, TOG5314, TOG5437, TOG5439, TOG5453, TOG5803, TOG6195, TOG6710, TOG7020 } \\
\hline & $\ldots$ & $\ldots$ & $\begin{array}{l}\text { TOG6202, TOG6206, TOG6238, TOG6356, } \\
\text { TOG6767, RAM98, RAM69, RAM77, RAM94, } \\
\text { TOG6308 }\end{array}$ & $\begin{array}{l}\text { IG02, TOG5293, TOG5406, TOG5447, TOG5458, } \\
\text { TOG5464, TOG5473, TOG5491, TOG5514, } \\
\text { TOG5523, TOG5533, TOG5566, TOG5591, } \\
\text { TOG5602, TOG5620, TOG5650, TOG5675, } \\
\text { TOG5810, TOG5882, TOG5953, TOG5989, } \\
\text { TOG5997, TOG6000, TOG6007, TOG6231, } \\
\text { TOG7173 }\end{array}$ \\
\hline \multirow[t]{2}{*}{ MR } & $\begin{array}{l}\text { TOG5672, } \\
\text { TOG6767 }\end{array}$ & $\begin{array}{l}\text { RAM63, } \\
\text { RAM94, } \\
\text { TOG5832 }\end{array}$ & \multicolumn{2}{|c|}{$\begin{array}{l}\text { CG17, RAM24, RAM90, TOG5283, TOG5420, TOG5486, TOG5540, TOG5672, TOG5680, TOG5681, } \\
\text { TOG5747, TOG5775, TOG5820, TOG5832, TOG6038, TOG6080, TOG6165, TOG6208, TOG6211 }\end{array}$} \\
\hline & $\ldots$ & $\ldots$ & $\begin{array}{l}\text { IG02, TOG5293, TOG5447, TOG5458, TOG5464, } \\
\text { TOG5473, TOG5523, TOG5566, TOG5620, TOG5650, } \\
\text { TOG5675, TOG5810, TOG5953, TOG5989, TOG6007, } \\
\text { TOG6231, TOG7173, TOG5286, TOG5287, TOG5324, } \\
\text { TOG5390, TOG5400, TOG5404, TOG5500, TOG5556, } \\
\text { TOG5641, TOG6208, TOG6221, TOG7420, RAM63, } \\
\text { RAM116, RAM123, MG12 }\end{array}$ & $\begin{array}{l}\text { TOG6202, TOG6206, TOG6238, TOG6356, } \\
\text { TOG6767, RAM98, TOG5307, TOG5429, } \\
\text { TOG5639, TOG5649, TOG5687, TOG5695, } \\
\text { TOG5885, TOG5923, TOG5980, TOG6181, } \\
\text { TOG6334, TOG7106, TOG7345, RAM55, RAM101, } \\
\text { Saliforeh }\end{array}$ \\
\hline S & \multicolumn{3}{|c|}{$\begin{array}{l}\text { RAM55, RAM112, TOG5307, TOG5639, TOG5649, TOG5666, TOG5687, } \\
\text { TOG5885, TOG5997, TOG6334, TOG7106, TOG7345, Saliforeh, Dckono, } \\
\text { PaDckono }\end{array}$} & $\begin{array}{l}\text { RAM2, RAM59, RAM63, RAM77, RAM94, RAM95, } \\
\text { RAM112, RAM116, RAM123, Dckono, PaDckono, } \\
\text { TOG5286, TOG5287, TOG5324, TOG5326, } \\
\text { TOG5400, TOG5404, TOG5556, TOG6221, } \\
\text { TOG6308 }\end{array}$ \\
\hline
\end{tabular}

\footnotetext{
a Reactions induced by $X$. oryzae pv. oryzae strains on $O$. glaberrima accessions: $\mathrm{R}=$ resistant, $\mathrm{MR}=$ moderately resistant, and $\mathrm{S}=$ susceptible. In bold: accessions that were both resistant to African X. oryzae pv. oryzae strain MAI1 (race A3) and moderately resistant to Asian strain PXO86 (Phil race 2). In bold and italic: accessions that were both resistant to Asian X. oryzae pv. oryzae strain PXO86 (Phil race 2) and moderately resistant to African X. oryzae pv. oryzae strain MAI1 (race A3).
}

Table 3. Disease reaction induced by Xanthomonas orzyzae pv. oryzae on Oryza sativa accessions

\begin{tabular}{|c|c|c|c|c|c|c|c|c|c|c|c|c|c|}
\hline \multirow[b]{3}{*}{ Acc. ${ }^{b}$} & \multirow[b]{3}{*}{ Subspecies } & \multicolumn{12}{|c|}{ Strains used $^{\mathrm{a}}$} \\
\hline & & \multicolumn{3}{|c|}{ BAI3 (race A1) } & \multicolumn{3}{|c|}{ BAI4 (race A2) } & \multicolumn{3}{|c|}{ MAI1 (race A3) } & \multicolumn{3}{|c|}{ PXO86 (Phil race 2) } \\
\hline & & $\mathbf{L L} \pm \mathrm{SE}$ & $\mathbf{T}$ & $\mathbf{V L}$ & $\mathbf{L L} \pm \mathbf{S E}$ & $\mathbf{T}$ & VL & $\mathbf{L L} \pm \mathbf{S E}$ & $\mathbf{T}$ & $\mathbf{V L}$ & $\mathbf{L L} \pm \mathbf{S E}$ & $\mathbf{T}$ & $\mathbf{V L}$ \\
\hline IR24 & Indica & $20.78 \pm 0.28$ & $S$ & 5 & $21.00 \pm 0.28$ & $\mathrm{~S}$ & 5 & $0.30 \pm 0.24$ & $\mathrm{R}$ & 1 & $15.33 \pm 0.24$ & $\mathrm{~S}$ & 4 \\
\hline IR64 & Indica & $3.88 \pm 0.28$ & $\mathrm{R}$ & 1 & $0.98 \pm 0.28$ & $\mathrm{R}$ & 1 & $0.27 \pm 0.24$ & $\mathrm{R}$ & 1 & $17.33 \pm 0.24$ & $\mathrm{~S}$ & 4 \\
\hline WAB165 & Japonica & $0.27 \pm 0.24$ & $\mathrm{R}$ & 1 & $3.20 \pm 0.28$ & $\mathrm{R}$ & 1 & $0.32 \pm 0.24$ & $\mathrm{R}$ & 1 & $17.08 \pm 0.24$ & $\mathrm{~S}$ & 4 \\
\hline BG90-2 & Indica & $0.24 \pm 0.28$ & $\mathrm{R}$ & 1 & $0.38 \pm 0.28$ & $\mathrm{R}$ & 1 & $0.41 \pm 0.24$ & $\mathrm{R}$ & 1 & $19.58 \pm 0.24$ & $\mathrm{~S}$ & 5 \\
\hline ITA212 & Indica & $7.10 \pm 0.28$ & MR & 2 & $7.28 \pm 0.28$ & MR & 2 & $2.73 \pm 0.24$ & $\mathrm{R}$ & 1 & $20.05 \pm 0.24$ & $\mathrm{~S}$ & 5 \\
\hline ITA306 & Indica & $3.07 \pm 0.29$ & $\mathrm{R}$ & 1 & $2.73 \pm 0.28$ & $\mathrm{R}$ & 1 & $2.77 \pm 0.24$ & $\mathrm{R}$ & 1 & $20.43 \pm 0.24$ & $\mathrm{~S}$ & 5 \\
\hline Kogoni & Indica & $2.05 \pm 0.28$ & $\mathrm{R}$ & 1 & $2.32 \pm 0.29$ & $\mathrm{R}$ & 1 & $2.40 \pm 0.24$ & $\mathrm{R}$ & 1 & $20.13 \pm 0.24$ & $\mathrm{~S}$ & 5 \\
\hline Azucena & Japonica & $22.48 \pm 0.23$ & $\mathrm{~S}$ & 5 & $22.48 \pm 0.23$ & $\mathrm{~S}$ & 5 & $16.45 \pm 0.17$ & $\mathrm{~S}$ & 4 & $25.58 \pm 0.19$ & $\mathrm{~S}$ & 5 \\
\hline
\end{tabular}

${ }^{\mathrm{a}} \mathrm{LL}=$ lesion length (mean, in centimeters) induced by the different $X$. oryzae pv. oryzae strains used and calculated with $\operatorname{Pr}>|\mathrm{t}|<0.0001$ using software $\mathrm{R}$; $\mathrm{SE}$ indicates the standard error; $\mathrm{T}=$ disease reaction as described in the text with $\mathrm{R}=$ resistant, $\mathrm{MR}=$ moderately resistant, $\mathrm{MS}=$ moderately susceptible, and $\mathrm{S}=$ susceptible; $\mathrm{VL}=$ virulence level as described in the text, where $0=$ no obvious lesion, $1=\mathrm{LL}$ of 1 to $3 \mathrm{~cm}, 2=\mathrm{LL}$ of 4 to $7 \mathrm{~cm}, 3=\mathrm{LL}$ of 8 to 12 $\mathrm{cm}, 4=\mathrm{LL}$ of 13 to $18 \mathrm{~cm}$, and $5=\mathrm{LL}>19 \mathrm{~cm}$ according to Vikal et al. (45).

b Accession name. 
carried the resistance alleles $x a 5$ and $X a 21$, respectively, and both were absent from IR24 (Table 4; data not shown). None of the 12 O. glaberrima accessions carried either allele, with the exception of RAM 95, which was heterozygous for xa5 (Table 4; data not shown).

\section{Discussion}

In summary, 107 different $O$. glaberrima accessions were tested for their resistance to $X$. oryzae pv. oryzae. Of those, 20 were found to be highly resistant to Mali strain MAI1 and 36 to Philippine strain PXO86. Only five moderately resistant accessions were identified against strains from Burkina. The 20 O. glaberrima accessions that were highly resistant to the $X$. oryzae pv. oryzae strain from Mali were highly susceptible to $X$. oryzae pv. oryzae strains from Burkina and Niger, suggesting that there are complex interactions between these African $X$. oryzae pv. oryzae strains and their respective resistance genes in $O$. glaberrima. There was no clear correlation between the resistance level of $O$. glaberrima accessions and their geographical origin or that of the $X$. oryzae $\mathrm{pv}$. oryzae strains tested. The $O$. glaberrima accessions identified as resistant might be useful for developing a breeding program in Mali. X. oryzae pv. oryzae strains originating from Mali belong exclusively to race $\mathrm{A} 3$, suggesting that this race is endemic to this country (9), but it is also possible that race A3 is widespread in parts of West Africa not yet surveyed. Further analyses are needed to determine the range of race $\mathrm{A} 3$.

Results from this study suggest that the Philippines $X$. oryzae pv. oryzae strain PXO86 (race 2) is highly similar to the African $X$. oryzae pv. oryzae strain MAI1 (race A3), specifically in terms of virulence on $O$. glaberrima. However, it should be noted that these two strains are genetically very distant (9). Interestingly, the different African $X$. oryzae pv. oryzae strains exhibited differential virulence and disease reactions on $O$. glaberrima accessions, despite the fact that they have conserved TALs (9), which are known to play a critical role in the rice- $X$. oryzae pv. oryzae interaction. $X$. oryzae pv. oryzae strains from the Philippines and Mali were not as virulent as strains from Burkina or Niger on O. glaberrima, suggesting that $O$. glaberrima may not be their natural host. In contrast, $X$. oryzae pv. oryzae strains from Burkina and Niger were highly virulent on $O$. glaberrima inducing predominantly susceptible reactions, suggesting a strong adaptation of such strains to $O$. glaberrima.

Based on the race pattern of African X. oryzae pv. oryzae strains on the set of NILs (9), we hypothesize that the few moderately resistant to resistant $O$. glaberrima accessions that were character- ized in this study carry some resistance genes (i.e., $\mathrm{Xa} 4, x a 5, \mathrm{Xa}$, and $X a 21)$. However, none of the $O$. glaberrima accessions tested had the $x a 5$ or $X a 21$ resistance alleles. Accession RAM 95 that was found to be heterozygous for $x a 5$ was found to have some parentage originating from $O$. sativa (A. Ghesquiere, personal communication). Conversely, when no $O$. glaberrima was found to be resistant in our study, such as is the case with BAI4, we can tentatively conclude that these resistance genes do not play a major role in resistance of $O$. glaberrima.

Of the different indica and japonica cultivars we evaluated, IR64 and Azucena had different disease reactions with the African $X$. oryzae pv. oryzae strains. Further research is needed, using comparative mapping of bacterial blight resistance to African $X$. oryzae pv. oryzae strains in the reference mapping population (IR64 $\times$ Azucena) (5), to determine if there are specific genes or quantitative trait loci (QTL) shared in common. Identification of new genes or QTL can then be studied in O. glaberrima by using interspecific bridges between the two cultivated species with improved crossability toward $O$. sativa (12).

Of the 30 known $\mathrm{Xa}$ genes, 4 (Xa21 [18], Xa23 [51], Xa27 $[10,11]$, and $X a 30$ [t] [6]) have been identified from wild rice species $O$. longistaminata, $O$. rufipogon, $O$. minuta, and $O$. nivara, respectively. Special attention needs to be given to the screening of other African wild rice species (e.g., O. longistaminata) for resistance to African $X$. oryzae pv. oryzae strains. Interestingly, various $O$. glaberrima accessions had a good level of resistance to $X$. oryzae pv. oryzae PXO86 (race 2) and may be good sources of resistance for breeding materials in the Philippines as well as for other Asian countries. Pathogen populations of $X$. oryzae pv. oryzae in the Philippines are highly variable, as revealed based on virulence and DNA fingerprinting analysis, and more than $10 \mathrm{X}$. oryzae pv. oryzae races have been reported here $(20,27)$. Also, new races have emerged to overcome resistance (8). Therefore, although $X$. oryzae pv. oryzae strains belonging to race 2 are widespread throughout the lowland areas of the Philippines (27), it will be necessary to screen the $O$. glaberrima accessions with other $X$. oryzae pv. oryzae Philippines strains representative of the different races.

Knowledge of pathogen population structure, particularly related to race, is needed to guide predictions of which resistant genes are most likely to be successful. Accordingly, we need to increase our $X$. oryzae pv. oryzae collections in West Africa. The $X$. oryzae pv. oryzae-resistant $O$. glaberrima accessions identified in our study should be evaluated with other $X$. oryzae pv. oryzae races, both in the greenhouse and the field. Indeed, the resistant $O$. glaberrima

Table 4. Reaction of a selected set of Oryza glaberrima accessions to Xanthomonas oryzae pv. oryzae strains and their genotypes using markers for xa5 and Xa21

\begin{tabular}{|c|c|c|c|c|c|c|c|c|c|c|c|}
\hline \multirow[b]{3}{*}{ Accession } & \multirow[b]{3}{*}{ Origin } & \multicolumn{4}{|c|}{ X. oryzae pv. oryzae strains $^{\text {a }}$} & \multirow{2}{*}{\multicolumn{6}{|c|}{ Genotypes of the accessions at loci $x a 5$ and $X a 21^{b}$}} \\
\hline & & \multicolumn{3}{|c|}{ African } & \multirow{2}{*}{$\begin{array}{c}\text { Asian } \\
\text { PXO86 } \\
\text { (Phil race 2) }\end{array}$} & & & & & & \\
\hline & & $\begin{array}{c}\text { BAI3 } \\
\text { (A1) }\end{array}$ & $\begin{array}{c}\text { BAI4 } \\
\text { (A2) }\end{array}$ & $\begin{array}{c}\text { MAI1 } \\
\text { (A3) }\end{array}$ & & $\begin{array}{r}x a 5 \\
(\mathbf{R})\end{array}$ & $\begin{array}{c}\mathrm{Xa5} \\
(\mathrm{S})\end{array}$ & $\begin{array}{c}x a 5 \\
\text { genotype }\end{array}$ & $\begin{array}{c}X a 21 \\
(\mathbf{R})\end{array}$ & $\begin{array}{c}x a 21 \\
(\mathbf{S})\end{array}$ & $\begin{array}{c}\text { Xa21 } \\
\text { genotype }\end{array}$ \\
\hline TOG6208 & Guinea & $\mathrm{S}$ & $\mathrm{S}$ & MR & MR & - & + & Хa5/Хa5 & - & + & $x a 21 / x a 21$ \\
\hline TOG6308 & Liberia & $S$ & $\mathrm{~S}$ & $\mathrm{R}$ & $\mathrm{S}$ & - & + & Хa5/Xa5 & - & + & $x a 21 / x a 21$ \\
\hline RAM24 & Mali & $\mathrm{S}$ & MS & MR & MR & - & + & Хa5/Хa5 & - & + & $x a 21 / x a 21$ \\
\hline RAM55 & Mali & $S$ & $\mathrm{~S}$ & $\mathrm{~S}$ & MR & - & + & Xa5/Xa5 & - & + & $x a 21 / x a 21$ \\
\hline RAM63 & Mali & MS & MR & MR & $\mathrm{S}$ & - & + & Хa5/Хa5 & - & + & $x a 21 / x a 21$ \\
\hline RAM90 & Mali & MS & $\mathrm{S}$ & MR & MR & - & + & Хa5/Xa5 & - & + & xa21/xa21 \\
\hline RAM95 & Mali & MS & $\mathrm{S}$ & MS & $\mathrm{S}$ & + & + & $x a 5 / X a 5$ & - & + & $x a 21 / x a 21$ \\
\hline TOG5307 & Nigeria & $\mathrm{S}$ & $\mathrm{S}$ & $\mathrm{S}$ & MR & - & + & Хa5/Хa5 & - & + & $x a 21 / x a 21$ \\
\hline TOG5500 & Nigeria & $\mathrm{S}$ & $\mathrm{S}$ & MR & MS & - & + & Хa5/Xa5 & - & + & $x a 21 / x a 21$ \\
\hline TOG6211 & Nigeria & $\mathrm{S}$ & $\mathrm{S}$ & MR & $\mathrm{S}$ & - & + & Хa5/Хa5 & - & + & $x a 21 / x a 21$ \\
\hline CG14 & Senegal & MS & $\mathrm{S}$ & $\mathrm{R}$ & $\mathrm{R}$ & - & + & Хa5/Xa5 & - & + & $x a 21 / x a 21$ \\
\hline CG17 & Senegal & $\mathrm{S}$ & $\mathrm{S}$ & MR & MR & - & + & Хa5/Хa5 & - & + & $x a 21 / x a 21$ \\
\hline IRBB5 & Philippines & $\mathrm{R}$ & $\mathrm{R}$ & $\mathrm{R}$ & $\mathrm{R}$ & + & - & $x a 5 / x a 5$ & - & + & $x a 21 / x a 21$ \\
\hline IRBB21 & Philippines & MS & MR & $\mathrm{R}$ & $\mathrm{R}$ & - & + & Ха5/Хa5 & + & - & Хa21/Хa21 \\
\hline IR24 & Philippines & $S$ & S & $\mathrm{R}$ & MS & - & + & $X a 5 / X a 5$ & - & + & $x a 21 / x a 21$ \\
\hline
\end{tabular}

${ }^{a}$ Reaction as defined in the text: resistant (R), moderately resistant (MR), moderately susceptible (MS), and susceptible (S).

${ }^{\mathrm{b}}$ Symbols + and - indicate presence or absence, respectively, of allele as detected by Shirasawa et al (40), the International Rice Research Institute (unpublished data), and Iyer and McCouch (14). 
accessions identified here may be used either in cross combinations with accessions carrying other genes or for deployment in specific geographical areas.

\section{Acknowledgments}

We thank USAID and the Generation Challenge Program (subprogram SP5), which partially supported this study through a fellowship (G4007.14.01.03GR04-9EC) provided to G. Djedatin; A.-A. Saïdou of IRD/University of Niamey for his support in data analysis; B. Szurek (IRD Montpellier) for helpful discussions; C. Gonzalez for initiating the work on $O$. glaberrima resistance screening during her Ph.D. thesis at IRD Montpellier; E. Mercado (IRRI) for performing the work on the detection of xa5 allele in O. glaberrima accessions; and $\mathrm{M}$. Reveche and D. Skinner for providing information on dot-blot assay. This work on allele detection was partly supported by the Generation Challenge Program (project 2005-18, Development of Low Cost Gene-Based Trait Assay Technologies in Cereals).

\section{Literature Cited}

1. Adhikari, T. B., Cruz, V. C. M., Zhang Q., Nelson, R. J., Skinner, D. Z., Mew, W., and Leach, J. E. 1995. Genetic diversity of Xanthomonas oryzae pv. oryzae in Asia. Appl. Environ. Microbiol. 61:966-971.

2. Alam, M. S., and Efron Y. 1986. Resistance to stalk eyed fly, Diopsis macroptholma. Dalman. Int. Rice Commun. Newsl. 31:40-45.

3. Albar, L., Bangratz-Reyser, M., Hébrard, E., Ndjiondjop, M.-N., Jones, M., and_Ghesquière, A. 2006. Mutations in the eIF (iso) 4G translation initiation factor confer high resistance of rice to Rice yellow mottle virus. Plant J. 47:417-426.

4. Baggie, I., Zapata, F., and Sangina, N. 2002. Genotypic response to aluminium toxicity of some rice. Int. Rice Res. Notes 27:42.

5. Boisnard, A., Albar, L., Thiéméle, D., Rondeau, M., Ghesquière, A. 2007. Evaluation of genes from eIF4E and eIF4G multigenic families as potential candidates for partial resistance QTLs to Rice yellow mottle virus in rice. Theor. Appl. Genet. 116:53-62.

6. Cheema, K. K., Grewal, N. K., Vikal, Y., Sharma, R., Lore, J. S., Das, A., Bhatia, D., Mahajan, R., Gupta, V., Bharaj, T., and Singh, K. 2008. A novel bacterial blight resistance gene from Oryza nivara mapped to $38 \mathrm{~kb}$ region on chromosome 4L and transferred to Oryza sativa L. Genet. Res. 90:397407.

7. Chu, Z. H., Fu, B. Y., Yang, H., Xu, C. G., Li, Z. K., Sanchez, A., Park, Y. J., Bennetzen, J. L., Zhang, Q. F., and S. P. Wang. 2006. Targeting xa13, a recessive gene for bacterial blight resistance in rice. Theor. Appl. Genet. 112:455-461

8. Cruz, C. M. V., Bai, J. F., Ona, I., Leung, H., Nelson, R. J., Mew, T. W., and Leach, J. E. 2000. Predicting durability of a disease resistance gene based on an assessment of the fitness loss and epidemiological consequences of avirulence gene mutation. Proc. Natl. Acad. Sci. USA 97:13500-13505.

9. Gonzalez, C., Szurek, B., Manceau, C., Mathieu, T., Sere, Y., and Verdier, V. 2007. Molecular and pathotypic characterization of new Xanthomonas oryzae strains from West Africa. Mol. Plant-Microbe Interact. 20:534-546.

10. Gu, K., Tian, D., Yang, F., Wu, L., Sreekala, C., Wang, D., Wang, G. L., and Yin, Z. 2004. High-resolution genetic mapping of Xa27(t), a new bacterial blight resistance gene in rice, Oryza sativa L. Theor. Appl. Genet. 108:800807.

11. Gu, K. Y., Yang, B., Tian, D. S., Wu, L. F., Wang, D. J., Sreekala, C., Yang, F., Chu, Z. Q., Wang, G. L., White, F. F., and Yin, Z. C. 2005. R gene expression induced by a type-III effectors triggers disease resistance in rice. Nature 435:1122-1125.

12. Gutierrez, A., Carabali, S., Giraldo, O. X., Martinez, C. P., Correa, F., Prado, G., Tohme, J., and Lorieux, M. 2010. Identification of a Rice stripe necrosis virus resistance locus and yield component QTLs using Oryza sativa $\times$ O. glaberrima introgression lines. BMC. Plant Biol. 10:6.

13. Iyer, A. S., and McCouch, S. R. 2004. The rice bacterial blight resistance gene xa5 encodes a novel form of disease resistance. Mol. Plant-Microbe Interact. 17:1348-1354

14. Iyer, A. S., and McCouch, S. R. 2007. Functional markers for xa5-mediated resistance in rice (Oryza sativa, L.) Mol. Breed. 19:291-296.

15. Jiang, G. H., Xia, Z. H., Zhou, Y. L., Wan, J., Li, D. Y., Chen, R. S., Zhai, W. X., and Zhu, L. H. 2006. Testifying the rice bacterial blight resistance gene xa5 by genetic complementation and further analyzing xa5 (Xa5) in comparison with its homolog TFIIA gamma 1. Mol. Genet. Genomics 275:354-366

16. Jones, M. P., Ding Kuhn, M., Aluko, G. K., and Semon, M. 1997. Interspecific Oryza sativa L. $\times$ O. glaberrima Steud. progenies in upland rice improvement. Euphytica 92:237-246.

17. Kauffman, H. E., Reddy, A. P. K., Hsieh, S. P. Y., and Merca, S. D. 1973. An improved technique for evaluating resistance to rice varieties of Xanthomonas oryzae. Plant Dis. Rep. 57:537-541.

18. Khush, G. S., Bacalangco, E., and Ogawa, T. 1990. A new gene for resistance to bacterial blight from O. longistaminata. Rice. Genet. Newsl. 7:121122.

19. Kottapalli, K. R., Narasu, M. L., and Jena, K. K. 2010. Effective strategy for pyramiding three bacterial blight resistance genes into fine grain rice cultivar, Samba Mahsuri, using sequence tagged site markers. Biotechnol. Lett. doi 10.1007/s10529-010-0249-1.

20. Leach, J. E., Rhoads, M. L., Cruz, C. M. V., White, F. F., Mew, T. W., and Leung, H. 1992. Assessment of genetic diversity and population structure of Xanthomonas oryzae pv. oryzae with a repetitive DNA element. Appl. Environ. Microbiol. 58:2188-2195.

21. Lee, K. S., Rasabandith, S., Angeles, E. R., and Khush, G. S. 2003. Inheritance of resistance to bacterial blight in 21 cultivars of rice. Phytopathology 93:147-152.

22. Lorieux, M., Reversat, G., Garcia Diaz, S. X., Denance, C., Jouvenet, N., Orieux, Y., Bourger, N., Pando-Bahuon, A., and Ghesquiere, A. 2003. Linkage mapping of Hsa- $1 \mathrm{Og}$, a resistance gene of African rice to the cyst nematode, Heterodera sacchari. Theor. Appl. Genet. 107:691-696.

23. Maji, T., Singh, B. N., and Akenova, M. E. 2001. Vegetative stage drought tolerance in $O$. glaberrima Steud and $O$. sativa $L$. and relationship between drought parameters. Oryza 38:17-23.

24. Mew, T. W. 1987. Current status and future prospects of research on bacterial blight of rice. Annu. Rev. Phytopathol. 25:359-382.

25. Mew, T. W., Alvarez, A. M., Leach, J. E., and Swings, J. 1993. Focus on bacterial blight of rice. Plant Dis.77:5-12.

26. Ndjiondjop, M. N., Albar, L., Fargette, D., Fauquet, C., and Ghesquiere, A 1999. The genetic basis of high resistance to yellow mottle virus (RYMV) in cultivars of the two cultivated rice species. Plant Dis. 83:22-24.

27. Nelson, R. J., Baraoidan, M. R., Cruz, C. M. V., Yap, I. V., Leach, J. E. Mew, T. W., and Leung, H. 1994. Relationship between phylogeny and pathotypes for the bacterial blight pathogen of rice. Appl. Environ. Microbiol. 60:3275-3283.

28. Nipah, J. O., Jones, M. P., Singh, B. N., Kantaka, O. S., and Sahrawat, K. L. 1997. Screening for tolerance for iron toxicity. Int. Rice Res. Notes 22:2627.

29. Notteghem, J. L. 1982. Breeding for disease resistance in upland rice in Africa. FAO-IITA Meeting on Durable Resistance Breeding, Ibadan-Nigeria.

30. Nwilene, F. E., Williams, U. T., Ukwungwu, M. N., Dakouo, D., Nacro, S., Hmadoun, A., and Kamara, S. I. 2002. Reactions of differential genotypes to African gall midge in West Africa. Intell. Pest Manage. 48:195-201.

31. Oka, H. I. 1958. Varietal variation and classification of cultivated rice Indian J. Genet. Plant Breed. 18:78-89.

32. Pinheiro, J., Bates, D., DebRoy, S., Sarkar, D., and the R Core team. 2009. nlme: Linear and Nonlinear Mixed Effects Models. R package version 3.193.

33. PlowRight, R. A., Coyne, D. L., Nash, P., and Jones, M. P. 1999. Resistance to the rice nematodes Heterodera sacchari, Meloidogyne graminicola and $M$. incognita in Oryza glaberrima and O. glaberrima $\times O$. sativa interspecific hybrids. Nematology 1:745-752.

34. R Development Core Team, 2008. R: A language and environment for statistical computing. R Foundation for Statistical Computing, Vienna. http://www.R-project.org.

35. Reckhaus, P. M. 1983. Occurrence of Bacterial-Blight of rice in Niger, West Africa. Plant Dis. 67:1039-1039.

36. Sahrawat, K. L., and Sika, M. 2002. Comparative tolerance of O. sativa and O. glaberrima rice cultivars for iron toxicity in West Africa. Int. Rice Res. Notes 27:30-31

37. Second, G. 1982. Origin of the genetic diversity of cultivated rice (Oryza spp.): study of the polymorphism scored at 40 isozymes loci. Jpn. J. Genet. 57:25-57

38. Semon, M., Nielsen, R., Jones, M. P., and McCouch, S. R. 2005. The population structure of African cultivated rice Oryza glaberrima (Steud.): evidence for elevated levels of linkage disequilibrium caused by admixture with $O$. sativa and ecological adaptation. Genetics 169:1639-1647.

39. Sere, Y., Onasanya, A., Verdier, V., Akator, K., Ouedraogo, L. S., Segda, Z., Mbare, M. M., Sido, A. Y., and Baso. A. 2005. Rice bacterial leaf blight in West Africa: preliminary studies on disease in farmer's field and screening. Asian J. Plant Sci. 4:577-579.

40. Shirasawa, K., Shiokai, S., Yamaguchi, M., Kishitani, S., Nishio, T. 2006 Dot-blot-SNP analysis for practical plant breeding and cultivar identification in rice. Theor. Appl. Genet. 113:147-155.

41. Silue, D., and Notteghem, J. 1991. Resistance of 99 Oryza glaberrima varieties to blast. Int. Rice Res. Newsl. 16:13-14

42. Song, W. Y., Wang, G. L., Chen, L. L., Kim, H. S., Pi, L. Y., Holsten, T., Gardner, J., Wang, B., Zhai, W. X., Zhu, L. H., Fauquet, C., and Ronald, P. 1995. A receptor kinase-like protein encoded by the rice disease resistance gene, Xa21. Science 270:1804-1806.

43. Sundaram, R. M., Vishnupriya, M. R., Laha, G. S., Rani, N. S., Rao, P. S., Balachandran, S. M., Reddy, G. A., Sarma, N. P., and Sonti, R. V. 2009. Introduction of bacterial blight resistance into Triguna, a high yielding, midearly duration rice variety. Biotechnology J 4:400-407.

44. Thiémélé, D., Boisnard, A., Ndjiondjop, M-N., Chéron, S., Séré, Y., Aké, S. Ghesquière, A., and Albar, L. 2010. Identification of a second major resistance gene to Rice yellow mottle virus, RYMV2, in the African cultivated rice species, O. glaberrima. Theor. Appl. Genet. 10:1300-1320.

45. Vikal, Y., Das, A., Patra, B., Goel, R. K., Sidhu, J. S., and Singh, K. 2007. Identification of new sources of bacterial blight (Xanthomonas oryzae pv. oryzae) resistance in wild Oryza species and O. glaberrima. Plant Genet. Res. 5:108-112. 
46. Wang, G. L., Song, W. Y., Ruan, D. L., Sideris, S., and Ronald, P. C. 1996. The cloned gene, Xa21, confers resistance to multiple Xanthomonas oryzae pv. oryzae isolates in transgenic plants. Mol. Plant-Microbe Interact. 9:850855.

47. White, F. F., and Yang, B. 2009. Host and Pathogen Factors Controlling the Rice-Xanthomonas oryzae Interaction. Plant Physiol. 150:1677-1686.

48. Williams, C. T., Hidievbie, O., Ukwungwu, M. N., Dakouo, D., Nacro, S., Hamadoun, A., and Kamara, S. I. 1999. Multilocational screening of $O$. sativa and $O$. glaberrima for resistance to African gall midge $O$. oryzovora. Int. Rice Res. Notes 24:26-27.

49. Xiang, Y., Cao, Y. L., Xu, C. G., Li, X. H., and Wang, S. P. 2006. Xa3, conferring resistance for rice bacterial blight and encoding a receptor kinase-like protein, is the same as Xa26. Theor. Appl. Genet. 113:13471355.

50. Yoshimura, S., Yamanouchi, U., Katayose, Y., Toki, S., Wang, Z. X., Kono, I., Kurata, N., Yano, M., Iwata, N., and T. Sasaki. 1998. Expression of Xa1, a bacterial blight-resistance gene in rice, is induced by bacterial inoculation Proc. Natl. Acad. Sci. USA 95:1663-1668.

51. Zhang, Q., Lin, S. C., Zhao, B. Y., Wang, C. L., Yang, W. C., Zhou, Y. L., Li, D. Y., Chen, C. B., and Zhu, L. H. 1998. Identification and tagging a new gene for resistance to bacterial blight (Xanthomonas oryzae pv. oryzae) from O. rufipogon. Rice. Genet. Newsl. 15:138-142. 